\title{
PENGEMBANGAN APLIKASI SISTEM INFORMASI GEOGRAFIS (SIG) BERBASIS WEB UNTUK MANAJEMEN PEMANFAATAN AIR TANAH MENGGUNAKAN PHP, JAVA DAN MYSQL SPATIAL (Studi Kasus di Kabupaten Banyumas)
}

\author{
Jumadi $*$ dan Sigit Widiadi $* *$ \\ * Fakultas Geografi Universitas Muhammadiyah Surakarta \\ E-mail: joemnoor@gmail.com \\ ** Dinas Energi dan Sumber Daya Mineral Kabupaten Banyumas \\ E-mail: swiadi@yahoo.com
}

\begin{abstract}
In the existing world of geographic information systems (GIS), desktop mapping has taken a critical role for managing and using spatial information for business. But desktop-based GIS application having any limitation for users. The research was conducted to develop the web-based GIS in order to manage groundwater exploration and production, preventing from uncontrolled exploration, using Java Applet, MySQL Spatial and PHP. The system development was designed by using waterfall model of system life cycle with following steps: 1) system requirements, 2) software requirements, 3) analysis, 4) program design, 5) coding, 6) testing, dan 7) operation, supported by reference study, observation, and peer discussion. The result shows that by using Java Applet, MySQL Spatial and PHP, web-based GIS for groundwater management is customizable to create spatial modeling and well log modeling, user friendly, interactive, interoperable, informative, and easy to access with LAN/WAN connected PC. The application is very belpful in order to balance between groundwater supply and production, groundwater level monitoring, water quality monitoring, and groundwater user monitoring. Hopefully, the implementation of the system will help the groundwater supply conservation for sustainable development.
\end{abstract}

Keywords: web GIS, spatial modeling, well log modeling, Java, MySQL Spatial

\section{PENDAHULUAN}

Air merupakan salah satu komponen vital dalam kehidupan. Sering dengan pertumbuhan penduduk, kebutuhan akan air bersih pun terus megalami peningkatan. Padahal jumlah air secara kuantitas tidak bertambah, bahkan secara kualitas banyak yang mengalami penurunan akibat pencemaran yang disebabkan oleh meningkatnya variasi dan intensitas aktivitas penduduk itu sendiri.

Menurut Santosa dan Adji (2007) kebutuhan pasokan air tanah terus meningkat seiring dengan perkembangan daerah serta meningkatnya kebutuhan hidup manusia (Sudarmadji, 2006). Kabupaten Banyumas merupakan salah satu daerah yang dengan pertumbuhan kebutuhan air tinggi. Berdasarkan data Kabupaten Banyumas dalam Angka tahun 2007 (BPS, 2007), pada tahun 2005 jumlah pasokan air bersih yang disalurkan oleh PDAM kepada masyarakat sebesar $11.383 .923 \mathrm{~m}^{3}$, terjadi peningkatan $6,16 \%$ dibandingkan dengan tahun 2004. Dari jumlah tersebut sebanyak $8.631 .101 \mathrm{~m}^{3}$ $(75,81 \%)$ disalurkan ke rumah tangga 
untuk kebutuhan domestik. Secara faktual, diperkirakan kebutuhan air rata-rata untuk keperluan domestik sampai tahun 2007 adalah sebesar $76.447 .020 \mathrm{~m}^{3} /$ tahun, sehingga untuk memenuhi kebutuhan air tersebut masyarakat lebih banyak menggunakan air tanah dengan membuat sumur gali, sumur pompa, atau sumur bor.

Upaya untuk menjaga kelestarian (sustainability) air tanah adalah dengan melakukan pengelolaan secara seksama mempertimbangkan berbagai komponen wilayah termasuk komponen fisik maupun komponen masyarakat. Komponen fisik terkait dengan daya dukung lingkungan terhadap keberadaan air tanah (eksistensi), sedangkan komponen masyarakat terkait dengan pola, intensitas, metode, dan jumlah pengambilan air tanah serta upaya konservasi maupun tindakan yang merugikan terhadap upaya konservasinya.

Komponen fisik yang terkait dengan keberadaan air tanah antara lain: curah hujan, kondisi geologi, kondisi geomorfologi, kondisi geohidrologi, keberadaan cekungan air tanah dan penggunaan lahan di suatu wilayah. Secara umum komponen-komponen tersebut relatif tetap kondisinya dalam mempengaruhi eksistensi air tanah. Adapun faktor masyarakat adalah faktor yang banyak mempengaruhi berkurangnya daya dukung lingkungan terhadap keberadaan air tanah. Misalnya eksplorasi yang berlebihan, pengrusakan lingkungan di wilayah imbuhan (recharge area), pencemaran lingkungan maupun pengambilan air tanah yang tidak sesuai prosedur. Dengan demikian perlu adanya kontrol yang memadai terhadap perilaku masyarakat dalam melakukan eksplorasi air tanah.

Upaya kontrol yang dapat dilakukan adalah dengan melakukan pengadministrasian secara konsisten terhadap usaha- usaha eksplorasi air tanah dari waktu ke waktu, sehingga tersusun basis data yang memadai untuk pengambilan kebijakan taktis dalam upaya pelestarian air tanah. Basis data tersebut terkait dengan kondisi kewilayahan yang mencakup komponen fisik tersebut di atas sebagai data dasar dalam setiap pengambilan keputusan. Oleh karena itu dibutuhkan adanya sistem informasi yang berbasis kewilayahan (spatial) atau umum dikenal dengan Sistem Informasi Geografis (SIG) agar dapat menampung komponenkomponen penting dari basis data yang akan disusun.

Keberadaan teknologi SIG telah memberikan kemudahan bagi banyak kalangan dalam mengelola dan memanfaatkan data spatial (geographic reffereced data). Namun demikian, software SIG berbasis desktop yang banyak dipakai selama ini memiliki keterbatasan terutama masalah aksesibilitas dan interopera-bilitasnya (Peng dan Zhang, 2004). Sebagai upaya untuk mengatasi keterbatasan tersebut, pengembangan aplikasi SIG dapat beralih menggunakan teknologi web. Di samping lebih aksesible dan interoperable, saat ini juga sudah banyak pilihan teknologi yang dapat dipakai dalam membangun SIG web, misalnya Peng dan Zhang (2004) juga Xi dan Wu (2008) menggunakan geography markup language (GML), scalable vector graphics (SVG), dan web feature service (WFS), Kamadjeu dan Tolentino (2006) menggunakan SVG dan MySQL, sedangkan Babu (2003) menggunakan Java dan MySQL untuk membangun aplikasi SIG berbasis web.

Salah satu teknologi yang dapat dijadikan alternatif adalah pemanfaatan sistem basis data MySQL. MySQL merupakan sistem basis data RDBMS (Relational Database Management System) yang mulai versi 4.1 menambahkan ekstensi spatial pada sistem basis datanya (Haryanto, 
2005). Ekstensi spatial memungkinkan untuk menyimpan objek-objek geografis yang dapat dipakai dalam aplikasi SIG. Kaitannya dengan hal ini, berdasarkan spesifikasi dari OGC, setiap objek MySQL Spatial (layer) disimpan pada tabel yang terpisah dalam database, dengan satu record pada tabel dari setiap elemen spatial (spatial feature). Di dalam tabel spatial, kolom geometry menyimpan informasi geometris pada masing - masing record. Kolom geometry mendukung untuk menyimpan point, line, polygon, multipoint, multiline, dan multipolygon (Anonymous, 2006; Anonymous, 2007).

Tipe data geometry secara hirarkis dapat dibagi lagi menjadi beberapa tipe data yang lebih spesifik (Gambar 1), antara lain: point, line, polygon, multipoint, multiline, dan multipolygon. Diantaranya berupa tipe abstrak (berwarna kelabu) yang berarti tipe data tersebut hanya dapat diisi dengan tipe data spatial yang lain, termasuk geometry. Dari beberapa tipe data abstrak tersebut hanya geometry yang dapat digunakan sebagai tipe kolom (Karlsson).
Teknologi yang digunakan untuk mengembangkan web SIG untuk mendukung pengelolaan air tanah di Kabupaten Banyumas dipilih dengan mempertimbangkan dua hal. Pertama, persyaratan khusus aplikasi SIG, antara lain kaya akan tampilan grafis, mendukung konten raster dan vektor serta mampu menangani data dalam jumlah yang besar (Lilley, Chair, dan Jackson, 2004). Kedua, fungsi SIG yang disampaikan oleh AbdulRahman (2008), di mana sistem harus mampu menyimpan, menstruktur, memanipulasi, menganalisis dan merepresentasikan data spatial. Berdasarkan kedua pertimbangan tersebut teknologi yang digunakan adalah MySQL Spatial, Java Applet dan PHP. MySQL Spatial berfungsi untuk menyimpan, menstruktur, memanipulasi, dan menganalisis data spatial sedangkan untuk merepresentasi-kannya digunakan Java Applet. Adapun PHP berfungsi sebagai penghubung antara Java Applet dan MySQL. Agar menghasilkan tampilan spatial yang dinamis. PHP akan membaca data spatial dari MySQL kemudian menuliskannya sebagai data berbasis teks yang dikirimkan ke browser.

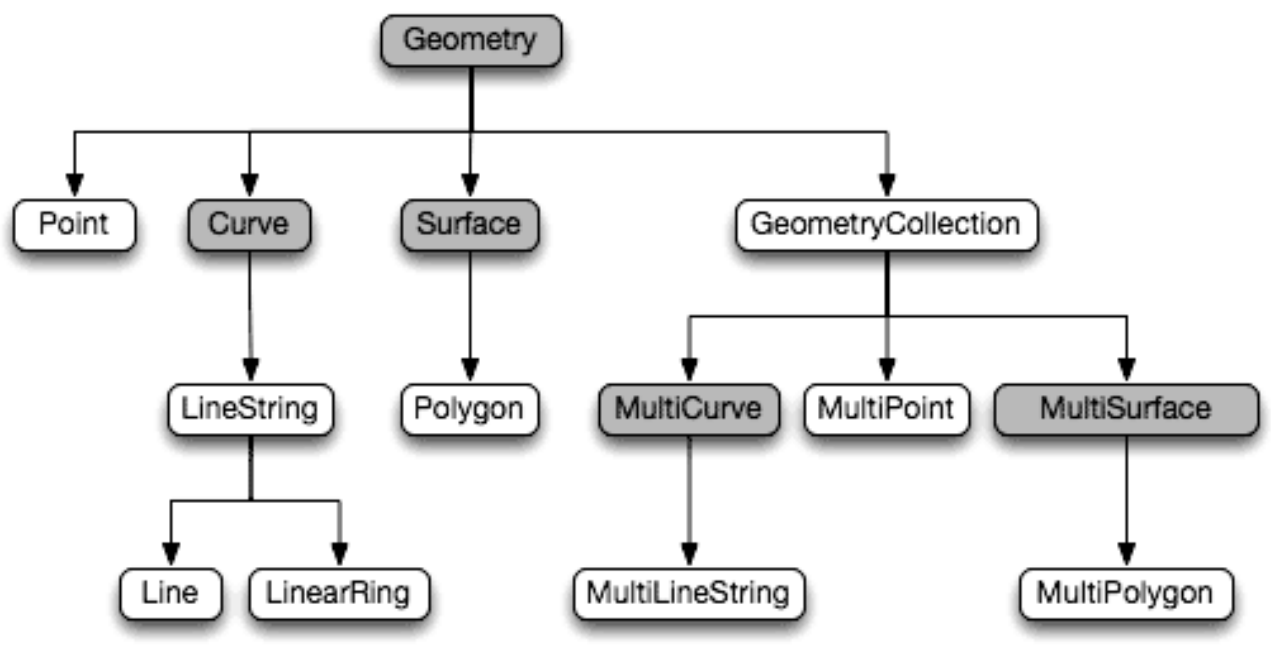

Sumber: Karlsson

Gambar 1. Hirarki Tipe Data MySQL Spatial 
Demikian pula sebaliknya, ketika user melakuan perubahan/penambahan secara interaktif pada Java Applet, PHP berfungsi untuk meng-eksekusi perubahan tersebut kedalam database MySQL.

Tujuan penelitian ini adalah untuk mendeskripsikan bagaimana pengembangan SIG berbasis web yang diimplementasi-kan untuk pengelolaan air tanah di Kabupaten Banyumas menggunakan Java, MySQL Spatial dan PHP. Mencakup pemanfaatanya dalam tujuan praktis pengelolaan air tanah. Sehingga diharapkan dapat memberikan wawasan teoritis dan aplikatif mengenai peranan Sistem Informasi Geografis.

\section{METODE PENELITIAN}

Tahapan pengembangan sistem yang digunakan dalam penelitian ini mengacu pada model waterfall (Demers, 1997), antara lain: 1) system requirements, 2) software requirements, 3) analysis, 4) program design, 5) coding, 6) testing, dan 7) operations (Gambar 2).
Model ini disebut waterfall karena satu tahapan tidak dapat dilaksanakan sebelum tahapan sebelumnya selesai, sehingga harus dilaksanakan secara berurutan.

Guna mendukung pelaksanaan tahapan tersebut dilakukan studi literatur, observasi, diskusi ahli:

a. Studi literatur: merupakan upaya untuk menjelajahi berbagai data dan informasi yang tertuang dalam buku, jurnal, laporan penelitian maupun informasi dari internet.

b. Observasi: merupakan upaya untuk penggalian data dan informasi mengenai pengelolaan air tanah yang selama ini dilakukan di Dinas Energi dan Sumber Daya Mineral Kabupaten Banyumas.

c. Diskusi ahli: merupakan upaya membahas berbagai data dan informasi yang dikemukakan oleh para ahli dengan latar belakang pengetahuan dan pengalaman dalam bidang geologi, geografi, teknologi informasi dan pengelolaan wilayah.

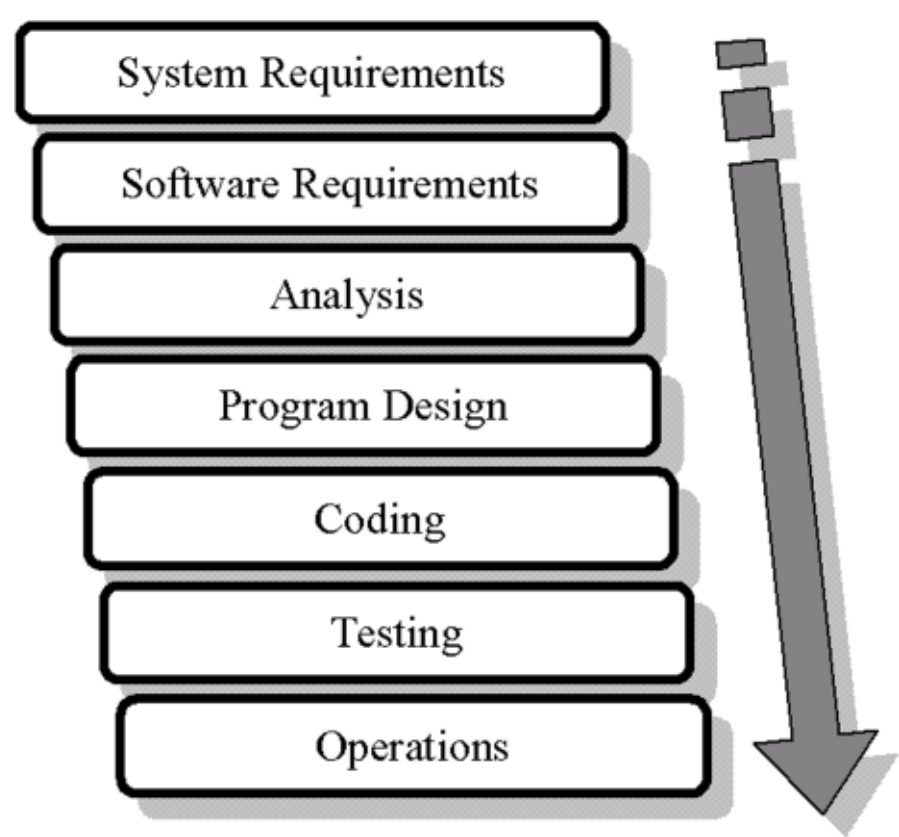

Sumber: Demers, 1997

Gambar 2. Tahapan Pengembangan Sistem Menggunakan Model Waterfall 
Proses penyusunan program (coding) meliputi penyusunan script PHP dan pembuatan Java Applet untuk membuat pemodelan spatial dan non spatial menggunakan NetBeans IDE 6.5 melibatkan beberapa program penting, antara lain:

1. Perangkat lunak yang berjalan di server (server-side), antara lain:
a. MySQL, berfungsi sebagai sistem basis data yang menyimpan baik data spatial maupun data non-spatial.
b. Apache, merupakan software yang berfungsi sebagai server web. dilakukan di server, baru kemudian hasilnya akan dikirimkan ke browser.
c. PHP, berfungsi pengerjaan scriptakan

2. Perangkat lunak yang berjalan di client (client-side), antara lain:

a. Internet Browser (Microsoft Internet Explorer, Mozila Firefox, Opera, dll), digunakan untuk browsing aplikasi.

b. Java Applet yang ditempelkan dalam aplikasi (embedded) untuk merepresentasikan data spatial secara dinamis dan interaktif.

c. Java Runtime Environtment (JRE), JRE berfungsi sebagai Java Virtual Machine (JVM) agar aplikasi java dapat berjalan.

\section{HASIL DAN PEMBAHASAN}

\section{Penyusunan Basis Data}

Basis data yang digunakan dalam aplikasi ini antara lain: pertama, basis data spatial yang terdiri atas data primer dan data sekunder. Data primer dengan melakukan survai ke lokasi sumur maupun area industri/pengguna air tanah, sedangkan data sekunder diperoleh dari hasil dokumentasi proyek dan penelitian serta peta Rupa Bumi Indonesia dalam format digital (Tabel 1).

Kedua, basis data non spatial yang juga terdiri atas data primer dan data sekunder (Tabel 2). Data primer diperoleh melalui survey dan pendataan, dan registrasi sedangkan data sekunder

Tabel 1. Data Spatial SIG untuk Pengelolaan Air Tanah

\begin{tabular}{lll}
\hline \hline \multicolumn{1}{c}{ Data } & \multicolumn{1}{c}{ Cara } \\
& Memperoleh & \multicolumn{1}{c}{ Sumber } \\
\hline Peta Geologi/Litologi skala 1:25.000 & Sekunder & Peta Digital \\
Peta Cekungan Air Tanah skala 1:25.000 & Sekunder & Peta Digital \\
Peta Kontur skala 1:25.000 & Sekunder & Peta Digital \\
Peta Produktivitas Akuifer skala 1:25.000 & Primer & Survai \\
Peta Wilayah Potensi skala 1:25.000 & Primer & Survai dan Analisis \\
Peta Konservasi skala 1:25.000 & Sekunder & Analisis dan Kebijakan \\
Peta Administrasi skala 1:25.000 & Sekunder & Peta Digital \\
Peta Lokasi dan Area Industri skala 1:10.000 & Primer & Survai \\
Peta Titik Minatan Sumur dan Mata Air skala 1:10.000 & Primer & Survai \\
Peta Pelengkap (jalan, jembatan, sungai) skala 1:25.000 & Sekunder & Peta Digital \\
\hline
\end{tabular}

Sumber: Anonymous (2004) dengan Modifikasi 
Tabel 2. Data Non - Spatial SIG untuk Pengelolaan Air Tanah

\begin{tabular}{lll}
\hline \hline \multicolumn{1}{c}{ Data } & \multicolumn{1}{c}{ Cara } \\
Memperoleh & & \multicolumn{1}{c}{ Sumber } \\
\hline Data Pengguna/Pemilik Sumur/Mata Air & Primer & Registrasi \\
Data Administrasi Sumur/Mata Air & Primer & Registrasi dan Survey \\
Data Hasil Analisis Lab. Air Tanah & Primer & Survey dan Analisis Lab. \\
Data Hasil Pemompaan (pumping test) & Primer & Survey \\
Data Hasil Observasi Tinggi Muka Air Tanah & Primer & Survey \\
Data Perijinan & Primer & Registrasi \\
Data Perusahaan Pelaksana Pengeboran & Primer & Registrasi \\
Data Perusahaan Pelaksana Studi & Primer & Registrasi \\
Hidrogeomorfologi & Primer & Survey \\
Foto - foto & Sekunder & Dokumen \\
Data pendukung lain & & \\
\hline
\end{tabular}

Sumber: Anonymous (2004) dengan Modifikasi

bersumber dari arsip dan dokumentasi kegiatan pengelolaan air tanah.

Data tersebut disimpan dalam sistem basis data, di mana setiap data disimpan dalam satu tabel MySQL. Tabel yang mengandung data spatial, seperti titik, garis, atau polygon, di dalamnya mengandung kolom bertipe data geometry yang digunakan untuk menyimpan data-data bereferensi geografis tersebut. Sekaligus tabel ini berfungsi sebagai layer-layer peta.

\section{Prosedur Sistem}

Sistem ini menggunakan beberapa peta dasar yang disimpan dalam basisdata (RDBMS) sebagai dasar untuk melaksanakan prosedur pengelolaan potensi air tanah, antara lain: peta geologi, peta geohidrologi, peta curah hujan, peta geomorfologi, peta lokasi sumur, peta konservasi air tanah, peta cekungan air tanah, dan peta potensi air tanah (Gambar 3). Data tersebut bersama dengan data lokasi calon pengguna dan lokasi rencana sumur digunakan untuk memberikan keputusan diterbitkan atau tidaknya surat ijin untuk melakukan eksplorasi air tanah di lokasi yang dikehendaki. Pada saat calon pengguna air tanah (masyarakat) mengajukan permohonan untuk melakukan eksplorasi air tanah (pengeboran), sistem akan meminta koordinat area sumur (persil) dan koordinat rencana pengeboran yang dapat diperoleh menggunakan GPS (Global Positioning System). Secara prosedural, pengukuran koordinat ini dilakukan oleh petugas yang bertindak sebagai surveyor dalam hirarki pengelola sistem.

Koordinat akan digunakan oleh sistem untuk melakukan query secara spatial (spatial query) mengacu pada analisis intersection pada MySQL spatial untuk 


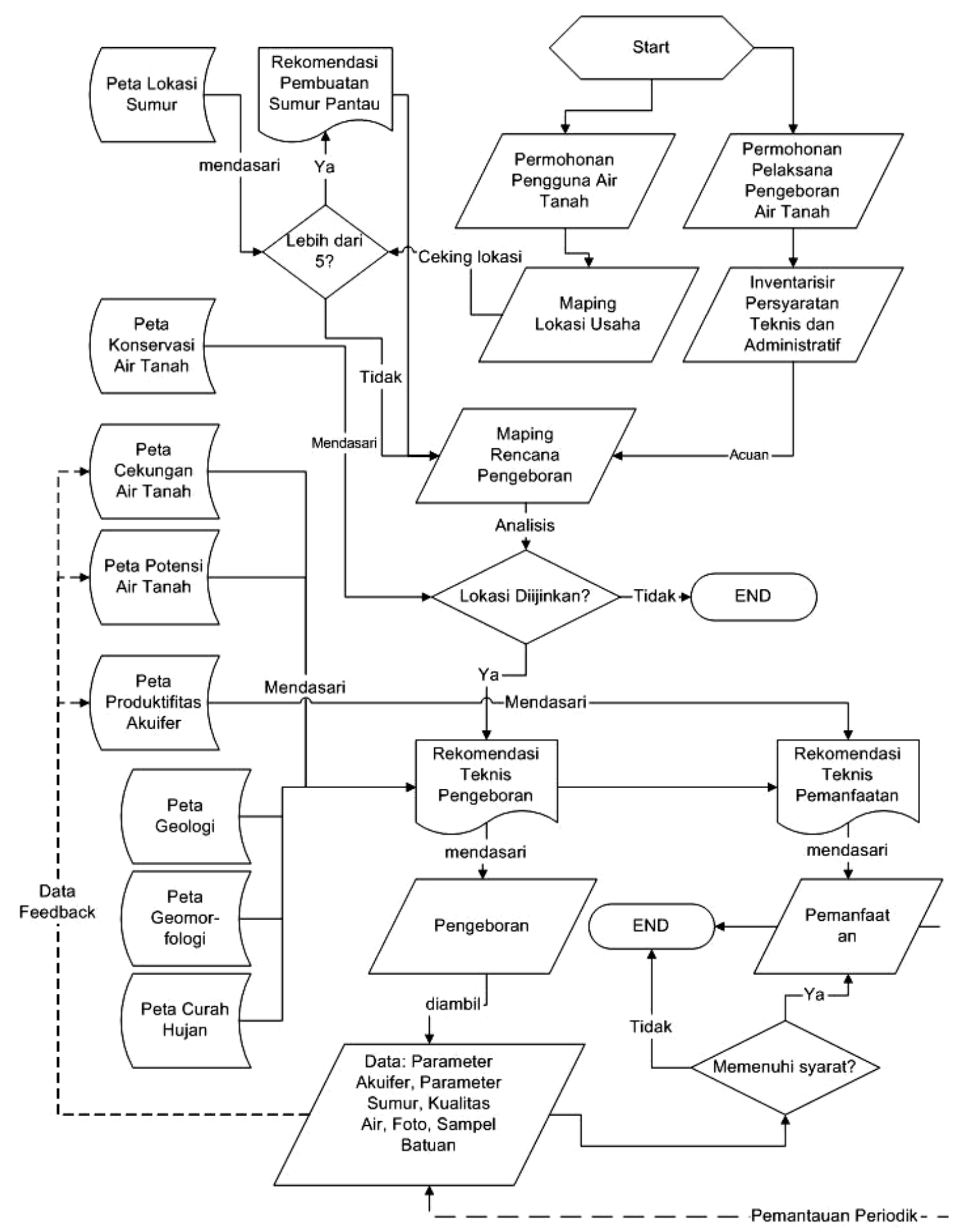

Sumber:Hasil Analisis

Gambar 3. Alur Prosedur SIG untuk Pengelolaan Air Tanah 
memperoleh informasi mengenai kondisi fisik lingkungan di mana sumur akan dibuat. Kondisi fisik ini mereferensi pada data dasar di atas, yakni informasi geologi, geohidrologi, curah hujan, geomorfologi, cekungan air tanah, dan potensi air tanah. Berdasarkan pada informasi tersebut, apabila menurut data konservasi air tanah lokasi diijinkan, pengguna akan melakukan analisis untuk membuat rekomendasi teknis pengeboran air tanah dan menerbitkan surat ijin pengeboran air tanah. Apabila berdasarkan data konservasi air tanah, lokasi tersebut tidak memungkinkan untuk dilakukan pengeboran (misalnya: merupakan daerah imbuhan (recharge area) atau daerah konservasi air tanah) maka sistem akan membatalkan permohonan untuk melakukan pengeboran air tanah.

Apabila pengeboran telah dilakukan, sistem akan meminta informasi mengenai perlapisan batuan yang ada pada lokasi pengeboran. Informasi ini selanjutnya akan digunakan untuk menerbitkan rekomendasi konstruksi, termasuk gambar konstruksi yang dibuat secara otomatis oleh aplikasi. Agar dapat diterbitkan rekomendasi pemanfaatan sumur yang berkaitan dengan jenis pemanfaatan dan debit pengambilan yang aman bagi lingkungan dan pelestarian ar tanah maka perlu dilakukan uji pompa (pumping test) untuk menentukan kuantitas air tanah dan uji laboratorium untuk menentukan kualitas air tanah.

Setelah data tersebut diperoleh, prosedur selanjutnya adalah pengecekan lapangan untuk melakukan verifikasi data dan pengambilan dokumentasi untuk penerbitan Surat Ijin Pemanfaatan Air (SIPA) . SIPA diterbitkan dengan jangka waktu tertentu, oleh karena itu selama masa waktu pemanfaatan sumur perlu dilakukan pemantauan secara periodik, termasuk penertiban apabila ditemui ketidak sesuaian antara SIPA dengan pemanfaatan yang dilakukan. Data hasil pemantauan ini selanjutnya digunakan sebagai dasar pengambilan keputusan mengenai keberlangsungan pemanfaatan sumur. Semua keputusan diorientasikan pada optimalisasi pemanfaatan dan pelestarian air tanah (Gambar 4).

\section{Desain Program (Program Design)}

\section{a. Arsitektur Sistem}

Sistem dirancang berbasis web menggunakan konsep arsitektur threetier, terdiri atas client-tier yag berjalan di browser, application-tier dibangun pada apache web sever dengan scripting menggunakan PHP dan Java Applet dan database-tier menggunakan MySQL yang berekstensi spatial (Gambar 5).

\section{b. Desain Antar Muka}

Desain antar muka halaman utama (interface) mencakup representasi spatial dan non spatial, menu, dan alat navigasi dan analisis geografis. Secara umum dibagi menjadi 9 bagian, antara lain (Gambar 6): 1) Header dan Title aplikasi; 2) Menu Utama; 3) Sub Menu; 4) Menu Navigasi Peta (map tools); 5) Tab layer control, legenda, dan penelusuran data; 6) Layer Control; 7) Ruang Peta (map space); 8) Inset Peta; 9) Panel penunjuk koordinat posisi pointer.

Selain alat analisis dan informasi, aplikasi juga dilengkapi dengan peralatan navigasi yang lengkap sehingga memudahkan pengguna untuk menyusuri data dan informasi. Termasuk juga peralatan untuk manajemen layer sehingga memungkinkan untuk membuat tampilan tematik (Gambar 7).

Form input data maupun output berupa pelaporan maupun pemodelan 


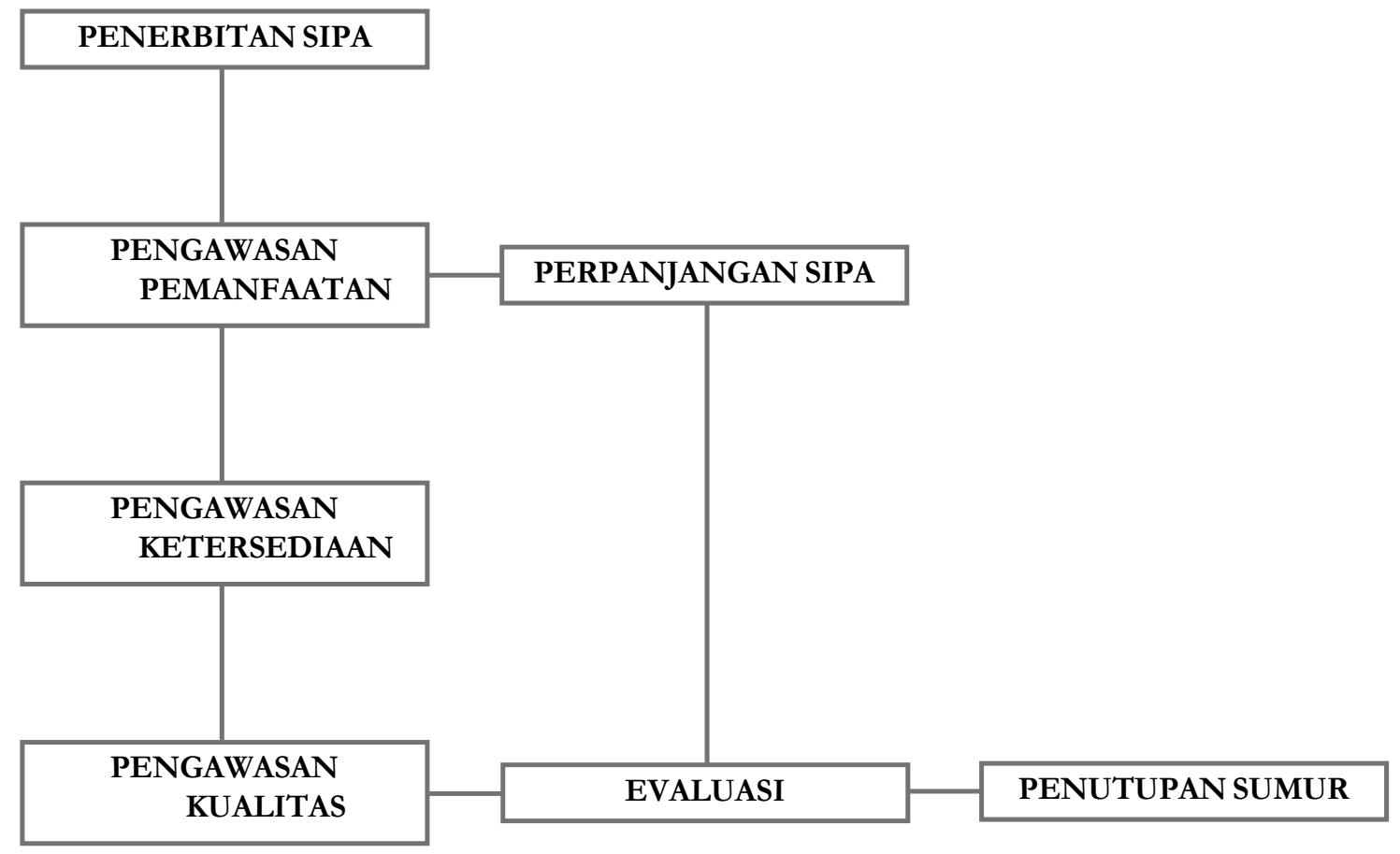

Sumber:Hasil Analisis

Gambar 4. Daur Hidup Sumur (Pemanfaatan Air Tanah)

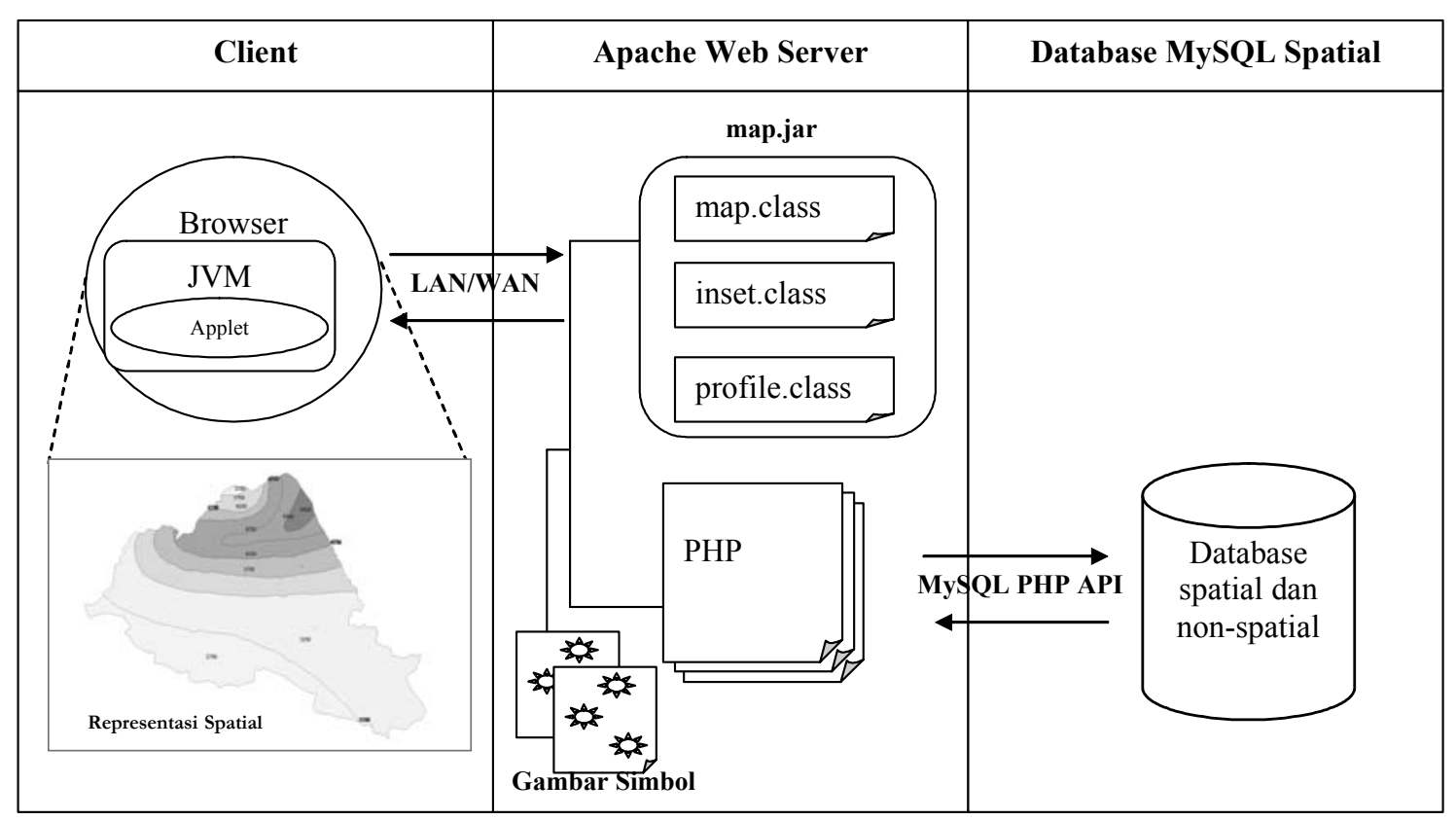

Sumber:Hasil Analisis

Gambar 5. Arsitektur SIG untuk Pengelolaan Air Tanah Berbasis Web 


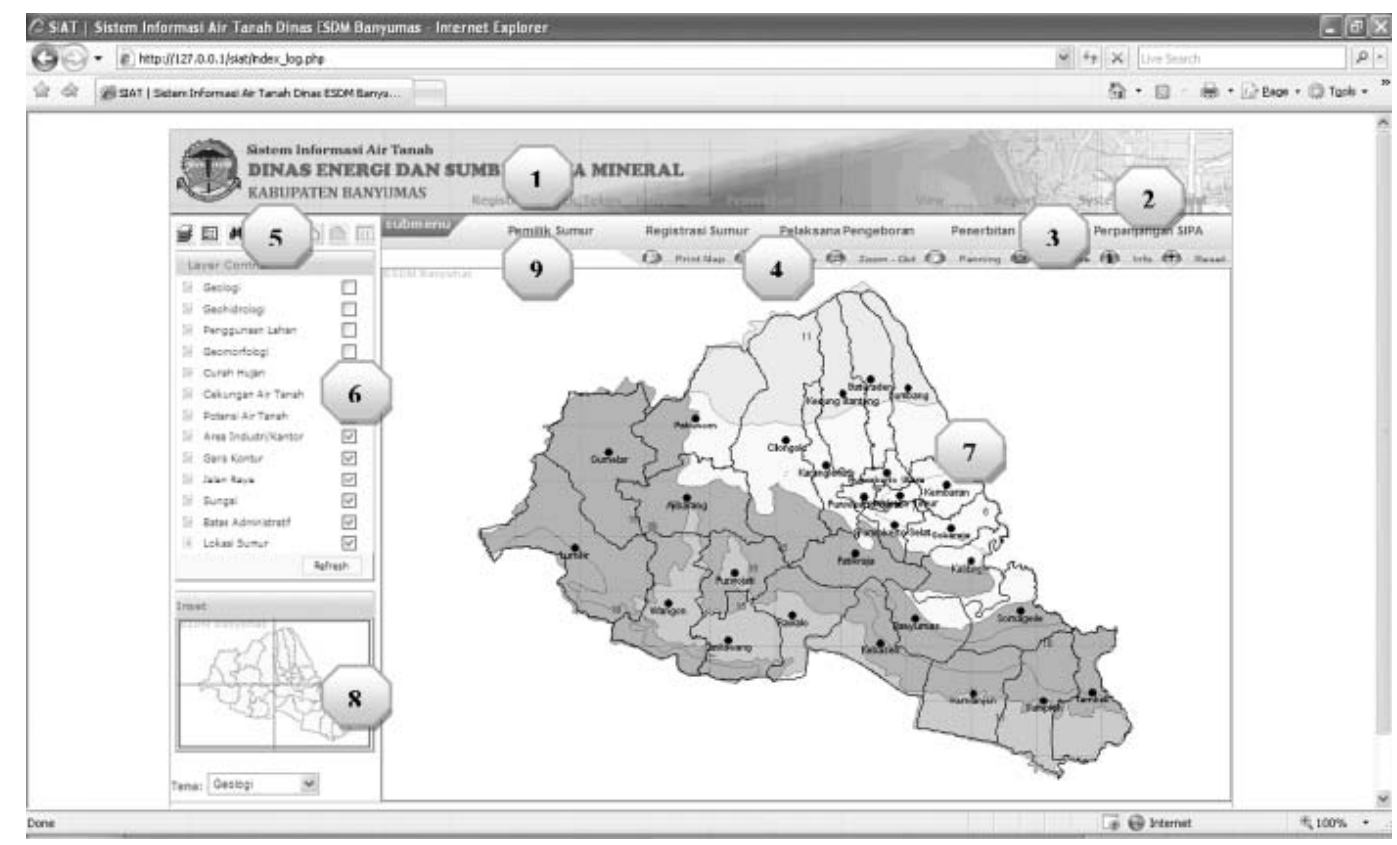

Keterangan:1) Header dan Title aplikasi; 2) Menu Utama; 3) Sub Menu; 4) Menu Navigasi Peta (map tools);5) Tab layer control, legenda, dan penelusuran data; 6) Layer Control; 7) Ruang Peta (map space); 8) Inset Peta; 9) Panel penunjuk koordinat posisi pointer

Sumber:Hasil Analisis

Gambar 6. Desain Antarmuka Halaman Utama

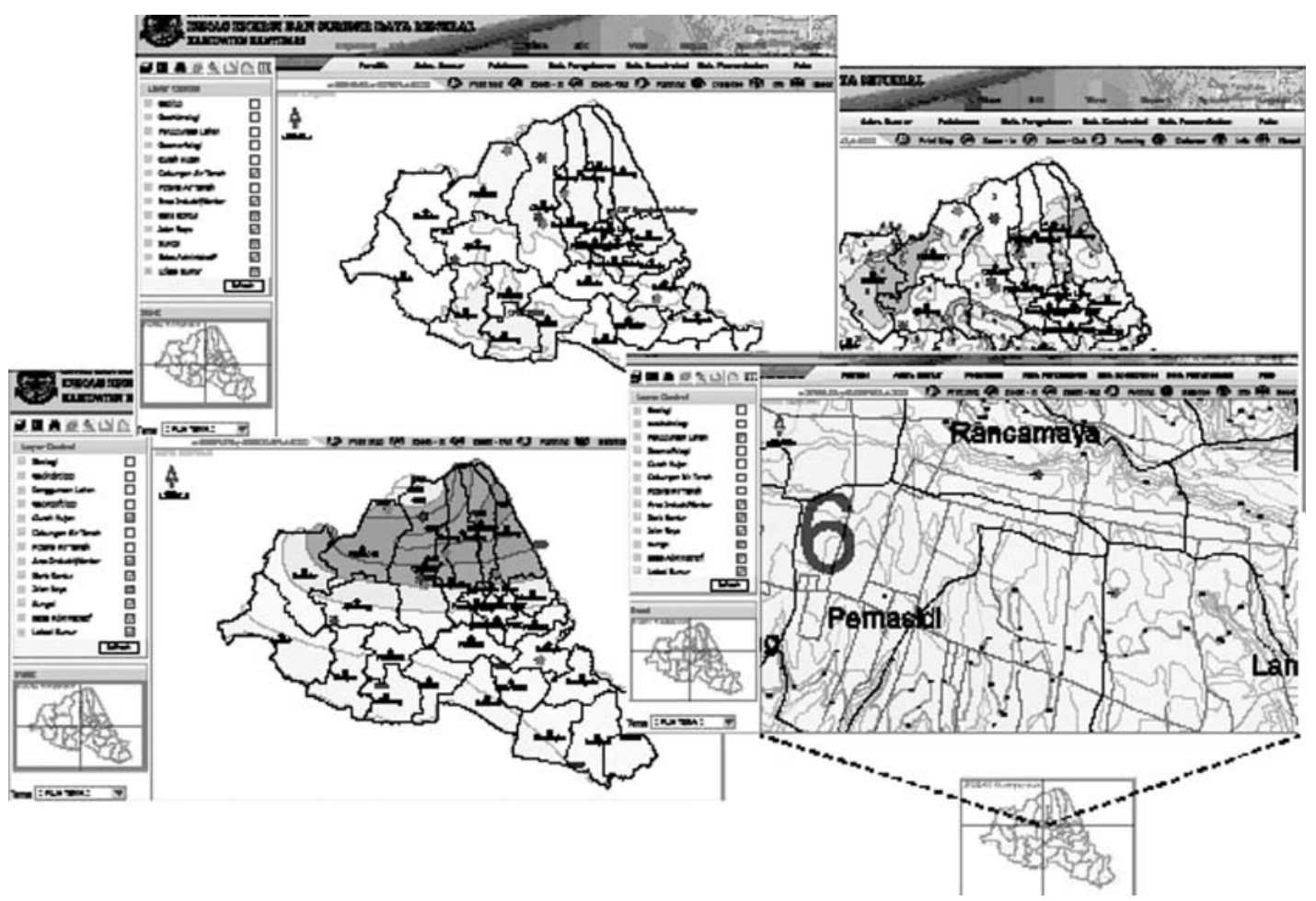

Sumber:Hasil Analisis

Gambar 7. Tampilan Tematik dan Navigasi Peta 
dibut sedemikian rupa agar mempermudah pengguna dalam mengoperasikan aplikasi. Optimalisasi kombobox dan pemanfaatan teknologi AJAX untuk menampilkan data-data isian standart pada form menghasilkan form yang interaktif serta mengurangi kesalahan dalam input data (buman error) (Gambar 8).

\section{c. Penulisan Program (coding) dan Representasi Data Spatial}

Penulisan program (coding) dalam pengembangan aplikasi ini terdiri atas 3 bagian, antara lain: 1) penulisan script PHP, 2) pembuatan Java Applet menggunakan bahasa java, dan 3) penulisan bahasa SQL untuk memanggil, menganalisis, menambah, mengedit, menghapus atau melakukan perintah eksekusi lain terhadap basis data MySQL. Perintah-perintah SQL ini masuk dan dieksekus didalam PHP.

PHP memiliki peranan penting tidak hanya dalam menghasilkan tampilan HTML yang dinamis tetapi juga berfungsi dalam komunikasi data antara server dengan applet. Berdasarkan konsep radius search, applet yang berfungsi untuk merepresentasikan data spatial mengirimkan request ke dokumen PHP yang ada diserver dengan memberikan parameter koordinat pusat yang diinginkan $(\mathrm{X}, \mathrm{Y})$, radius (distance) dan parameter status layer yang dikehendaki (Gambar 9).

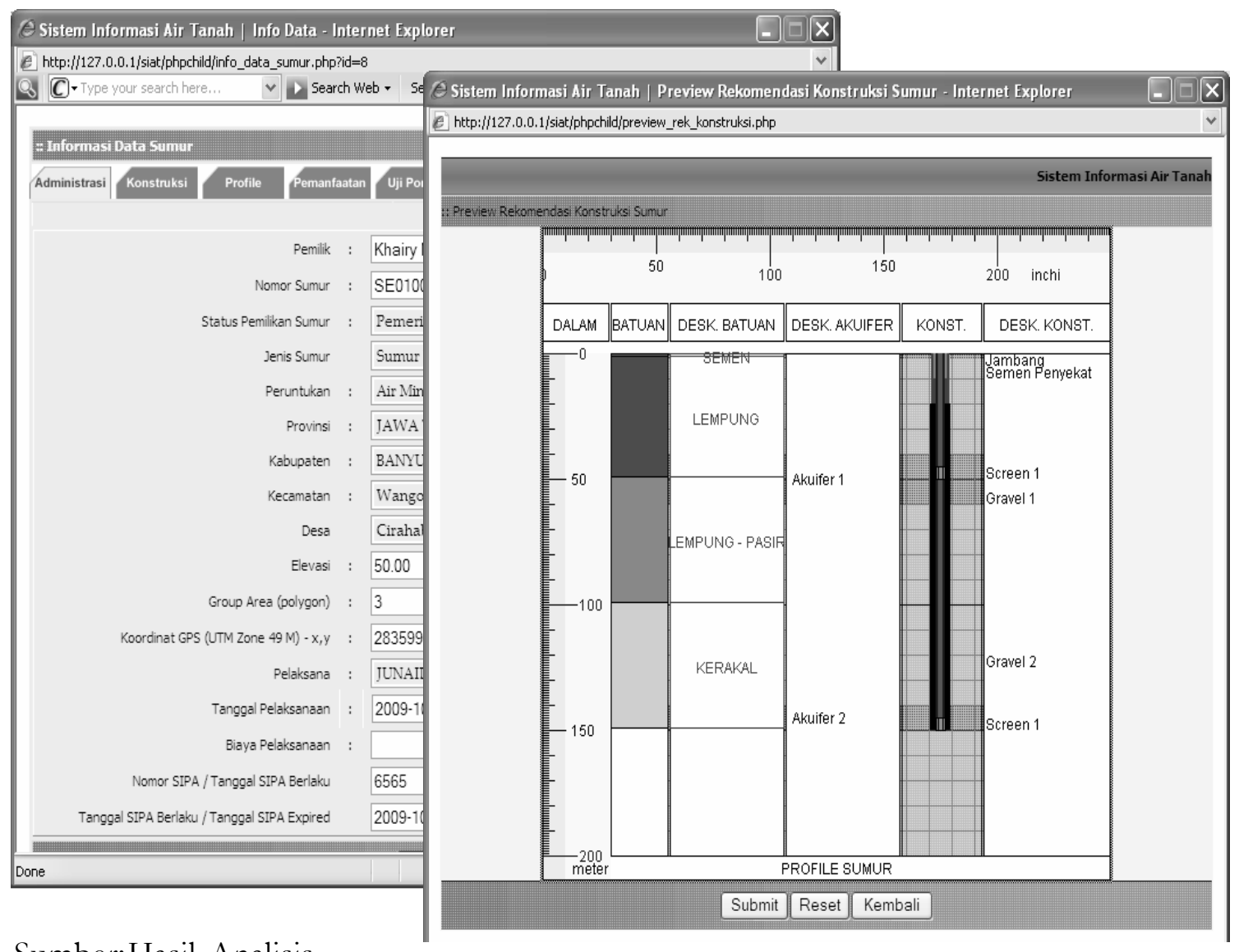

Sumber:Hasil Analisis

Gambar 8. Beberapa Contoh Tampilan Form dan Pemodelan Sumur 

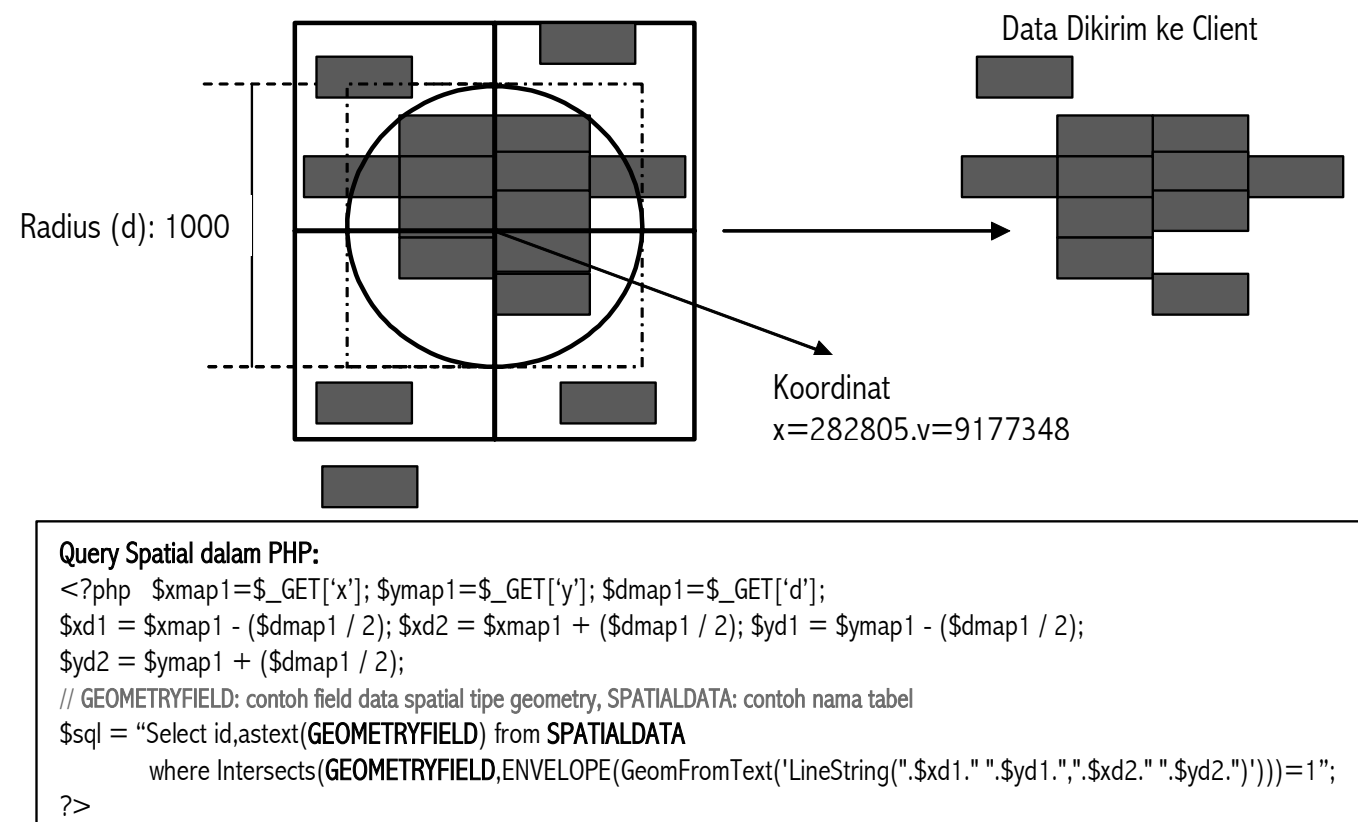

Sumber:Hasil Analisis

Gambar 9. Konsep Radius Search untuk Query Data Spatial Menggunakan Intersection

Pada saat melakukan query data dalam tipe geometry dikonversi menjadi teks, selanjutnya PHP mengirimkan ke applet di client. Applet akan mengkonversi data yang berupa kumpulan koordinat - kordinat dengan delimiter (Gambar 10). Dari data tersebut applet, dengan memanfaatkan java.awt.Graphics2D ditampilkan dalam format vektor dengan tampilan grafis berkualitas tinggi.

\section{Implementasi Sistem dalam Manajemen Air Tanah}

Sistem ini diimplementasikan dalam proses pengelolaan pemanfaatan air tanah, antara lain: 1) pemantauan lokasi sumur; 2) informasi awal tentang kondasi lokasi rencana sumur berkaitan dengan kondisi geologi, geohidrologi, curah hujan, geomorfologi, cekungan air tanah, potensi air tanah dan wilayah konservasi air tanah; 3) inventarisasi data perlapisan batuan;4) penerbitan rekomendasi dan perijinan; 5) pemantauan kuantitas dan kualitas air tanah; 6) pemantauan dan penertiban pemanfaatan air tanah; 7) pelaporan administratif dan pemanfaatan air tanah; dan 8) pemodelan spatial lokasi sumur; dan 9) pemodelan perlapisan batuan dan konstruksi sumur.

Informasi pemanfaatan air tanah yang ditampilkan secara spatial serta informasi kondisi fisik wilayah (Gambar 11) menggunakan aplikasi ini dapat dimanfaatkan sebagai landasan dalam pengambilan keputusan. Dikaitkan dengan basis data yang sudah dihimpun pengguna dapat memutuskan apakah permohonan pengeboran sumur air tanah disuatu lokasi dijinkan atau tidak dijinkan baik terkait 


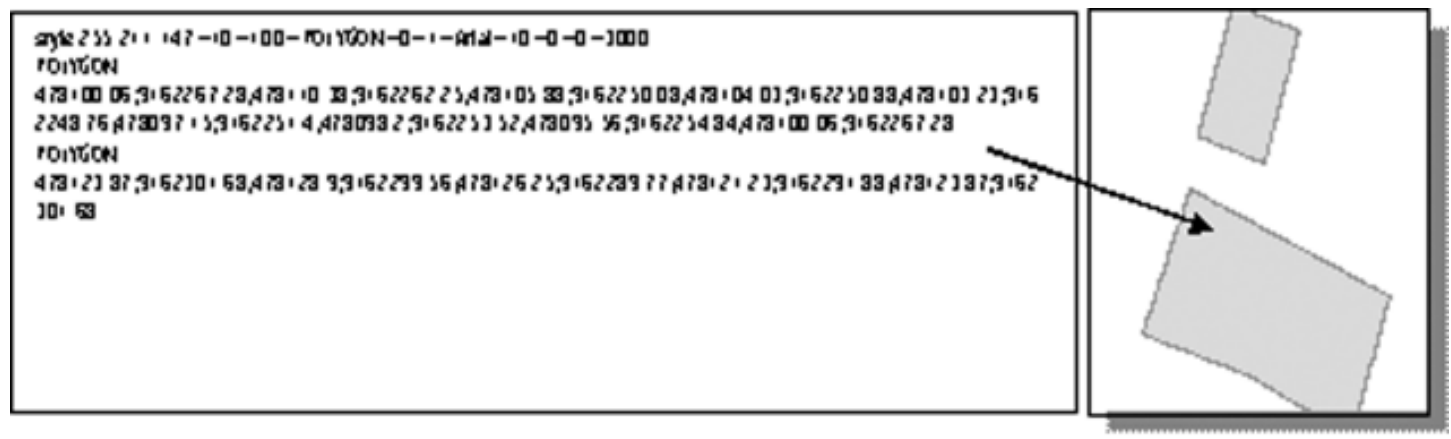

Sumber:Hasil Analisis

Gambar 10. Contoh Data Hasil Konversi dari geometry yang Dikirim ke Applet dan Representasi Grafisnya

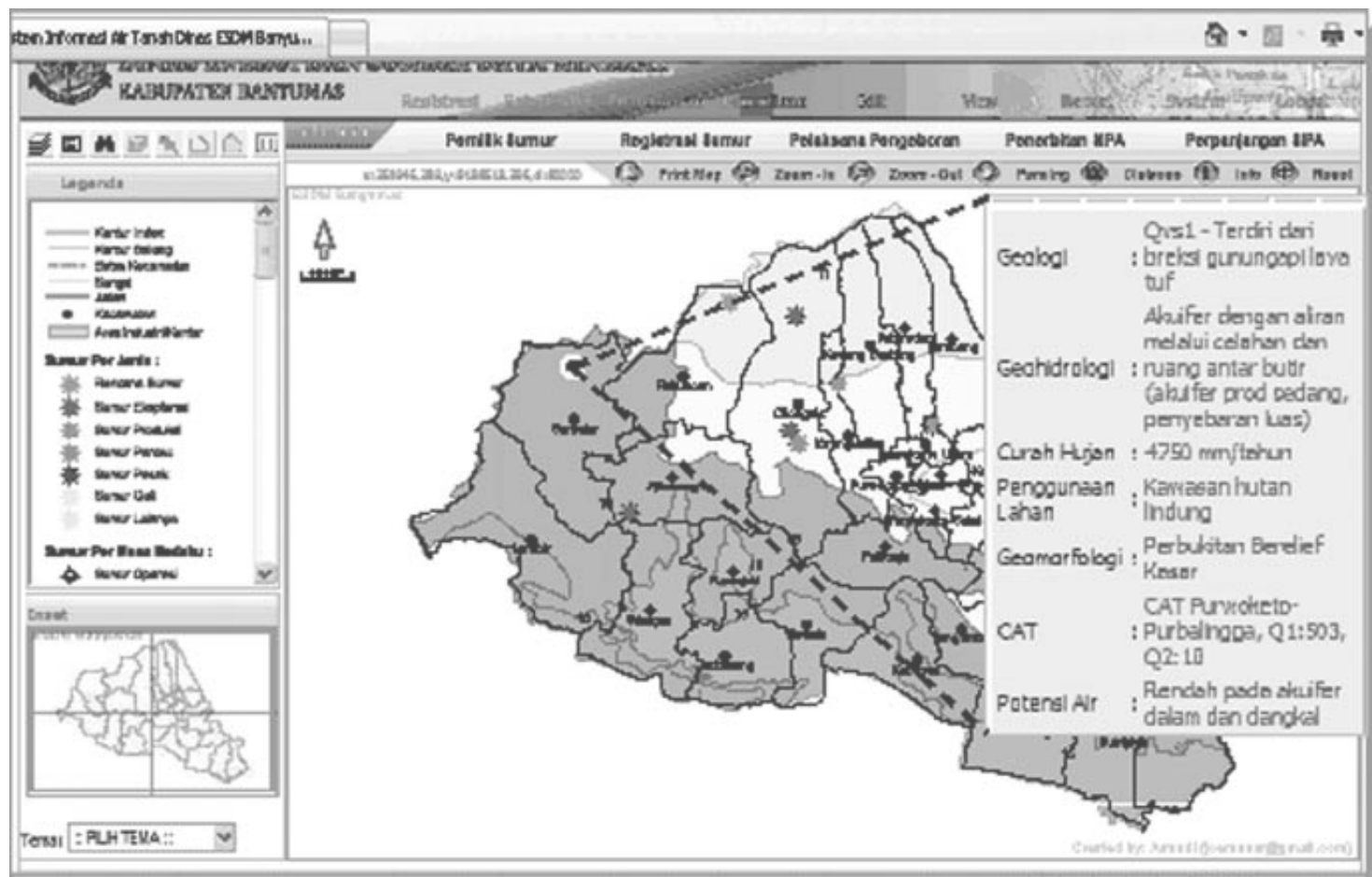

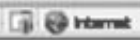

Sumber:Hasil Analisis

Gambar 11. Tampilan Informasi Kondisi Fisik Wilayah

dengan daya dukung lingkungan fisiknya, potensi air tanah menurut observasi yang sudah ada maupun kaitannya dengan kebijakan wilayah konservasi air tanah. Apabila diijinkan, informasi tersebut berguna dalam pembuatan rekomendasi rencana rancang bangun konstruksi sumur serta kedalaman pengeboran air tanah. Dengan demikian diharapkan diperoleh keputusan yang tepat dalam rangka 
menjaga keberlanjutan pemanfaatan air tanah.

Kaitannya dengan perencanaan lokasi pengeboran pemanfaatan air tanah pada sumur-sumur produksi dengan kapasitas pengambilan debit yang besar, aplikasi ini dapat secara cepat dipakai untuk mengetahui jarak (Gambar 12) antara rencana sumur yang akan dibangun dan sumur yang sudah ada di sekitarnya. Dengan demikian diharapkan dapat secara tepat mengatur posisi-posisi sumur tersebut agar drawdown yang terjadi pada saat pengambilan air tidak mempengaruhi kapasitas produksi sumur-sumur di sekitarnya (sumur masyarakat).

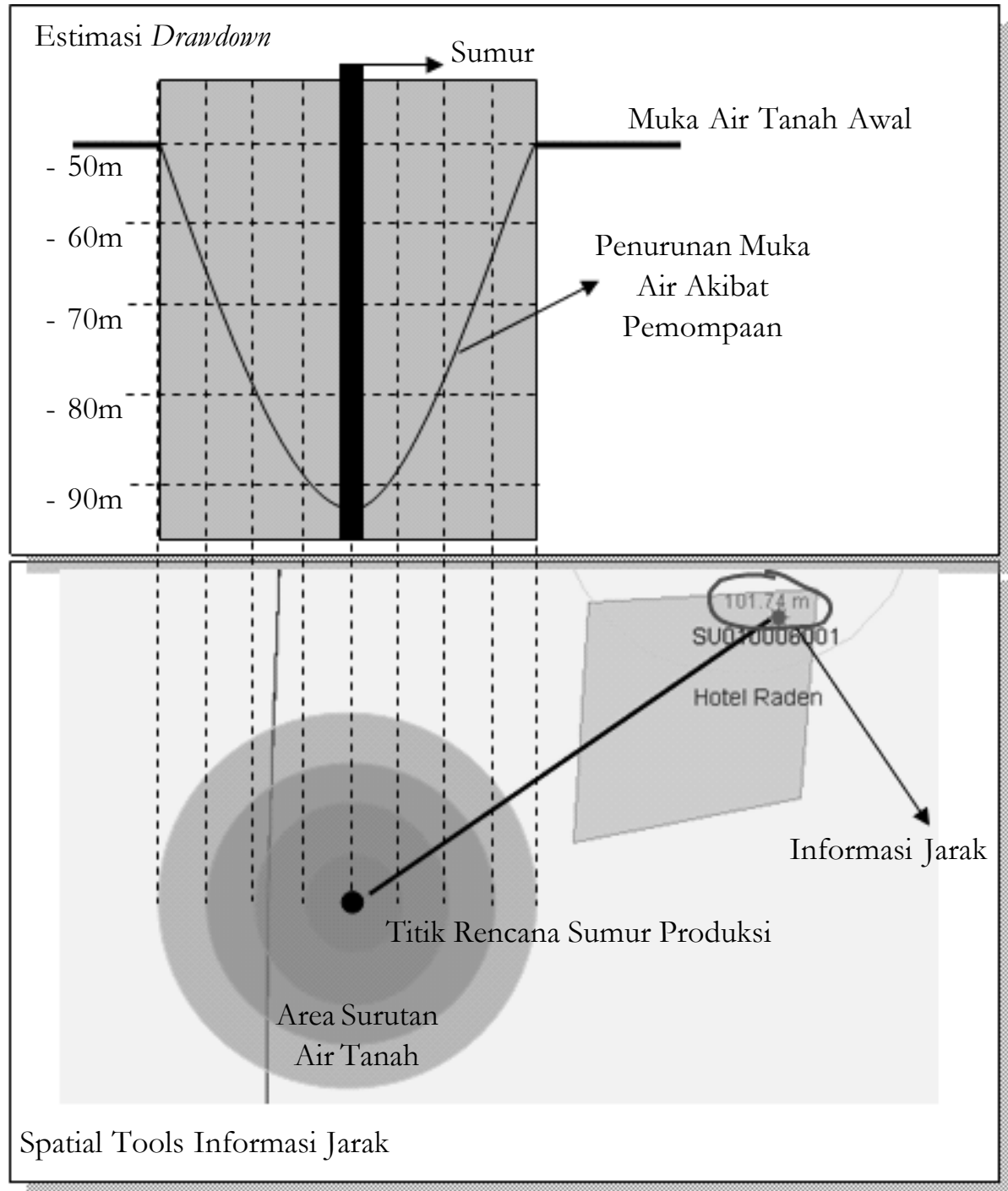

Sumber: Hasil Analisis

Gambar 12. Informasi Jarak Secara Spatial dikaitkan dengan Optimalisasi Posisi Pengambilan Air Tanah Menurut Perkiraan Drawdown 


\section{KESIMPULAN}

Sistem Informasi Geografis sangat bermanfaat untuk melaksanakan manajemen air tanah. Banyak fungsi manajerial dan pengambilan keputusan yang dapat dibantu menggunakan sistem ini, misalnya penerbitan rekomendasi maupun perijinan yang memungkinkan tersedianya informasi kewilayahan secara cepat menyangkut variable-variabel penting yang digunakan dalam upaya menjaga kelestarian air tanah. Bahkan dengan teknologi Java Applet, MySQL Spatial dan PHP memudahkan bagi pengembang untuk membuat pemodelan spatial maupun non spatial.

\section{UCAPAN TERIMA KASIH}

Penulis mengucapkan terima kasih kepada Dinas Energi dan Sumber Daya Mineral Kabupaten Banyumas, secara khusus kepada Kepala Dinas dan Bp. Junaidi atas sumbang saran yang Bapak berikan serta beberapa data yang menjadi rujukan dalam tulisan ini.

\section{DAFTAR PUSTAKA}

Anonymous. 2004. Kumpulan Teknis Pengelolaan Air Tanah. Jakarta: Departemen Energi dan Sumber Daya Mineral.

Abdul-Rahman, A., \& Morakot, P. 2008. Spatial Data Modelling for 3D GIS (5th ed.). Berlin: Springer.

Anonymous. 2006. Linking to MySQL Spatial Layers. Nebraska: MicroImages, Inc.

Anonymous. 2007. MySQL 5.1 Refference Manual. Boston: Free Software Foundation, Inc.

Anonymous. 2009. Sun Expands Identity Management Suite With New MySQL Database Interoperability for Dramatically Lower TCO. Information Technology Business. Atlanta: Mei 2009: 133.

Babu, M. N.. 2003. Implementing Internet GIS with Java Based Client-Server Environment. Map Asia Conference 2003.

Bouchard, Dany. 2005. Using GIS data intelligence on the web with Scalable Vector Graphics (SVG). The Netherlands: SVG Open 2005 conference Enschede.

Demers, Michael N. 1997. Fundamentals of Geographic Information System . New York: John Wiley \& Sons, Inc.

Di Glacomo, Mariella. 2005. MySQL: Lessons Learned on a Digital Library. IEEE Software; Vol. 22 (3) Mei/ Juni 2005: 10-13, 4p. ISSN: 07407459. Diakses 14 November 2009, dari Academic Source Premier. (Document ID: 16978944).

Dunfeya, R. I., Gittings, B. M., \& Batchellera, J. K.. 2006. Towards an open architecture for vector GIS. Computers \& Geosciences, Vol. 32 (10), Desember 2006: 1720-1732. 
eSpatial. 2009. eSpatial Announces Full Function Web GIS Geographic Information Systems as Software as a Service SaaS. Information Technology Business,106. Diakses 12 September 2009, dari Academic Research Library. (Document ID: 1675433601).

Haryanto, S. 2005. SQL: Kumpulan Resep Query Menggunakan MySQL. Jakarta: Dian Rakyat.

Kamadjeu, R., \& Tolentino, H. 2006. Open Source Scalable Vector Graphics Components for Enabling GIS in Webbased Public Health Surveillance Systems. AMIA 2006 Symposium Proceedings, 973.

Kang, J. S., You, Y., Sung, M. Y., Jeong, T. T., \& Park, J. 2008. Mobile Mapping Service using Scalable Vector Graphics on the Human Geographic. Seventh IEEE/ACIS International Conference on Computer and Information Science.

Karlsson, Anders. GIS and Spatial Extensions with MySQL. dari http://dev.mysql.com/ tech-resources/articles/4.1/gis-with-mysql.html, diakses tanggal 14 November 2009.

Lilley, C., Chair, and Jackson, D..2004. 2d Graphics in XML. dari http://www.w3.org/ Graphics/SVG/. Diakses 12 September 2009.

Mikhalenko, Peter V.. 2006. Explore W3C standards: Make SVG more active with sXBL. CNET Networks, Inc.

Neumann, A., \& Andréas M, W. 2000. Vector-based Web Cartography: Enabler SVG. Diakses tanggal 5 Agustus 2008, dari www.carto.net.

Oxley, Alan. 2009. Web 2.0 Applications of Geographic and Geospatial. Bulletin of the American Society for Information Science and Technology. April/May 2009 - Vol. 35 (4).

Peterson, Michael P.. 2003. Maps and the Internet. ELSEVIER - INTERNATIONAL CARTOGRAPHIC ASSOSIATION, UK: Elsevier Scient, ltd. ISBN: 0-08-044201-3.

Seff, George. 2002. Scalable Vector Graphics and Geographic Information Systems. Limbic Systems, Inc.

Santosa, W. S \& Adji, N. A.. 2007. The Investigation of Ground Water Potential by Vertical Electrical Sounding (VES) Approach in Arguni Bay Region, Kaimana Regency, West Papua. Forum Geografi. Vol. 21(1) Juli 2007.

Sudarmadji. 2006. Perubahan Kualitas Air tanah di Sekitar Sumber Pencemar Akibat Bencana Gempa Bumi. Forum Geografi. Vol 20 (2) Desember 2006: 91-119.

Xi, Yan-tao \& Wu, Jiang-guo. 2008. Application of GML and SVG in the development of WebGIS. Journal of China University of Mining and Technology. Vol. 18 (1), Maret 2008: $140-143$.

Peng, Z. \& Zhang, C.. 2004. The roles of geography markup language (GML), scalable vector graphics (SVG), and Web feature service (WFS) specifications in the development of Internet geographic information systems (GIS). Journal of Geographical Systems, 6(2), 95-116. Diakses 11 September 2009, dari Academic Research Library. (Document ID: 848873401). 